\title{
An Investigation of Diesohol-Biodiesel Mixture in Performance-Emission Characteristics of a Single Cylinder Diesel Engine: A Trade-Off Benchmark
}

\author{
S. Dey ${ }^{1 *}$, M. Deb ${ }^{2}$ and P. K. Das ${ }^{2}$ \\ ${ }^{1}$ Mechanical Engineering Department, National Institute of Technology Agartala, \\ 799046, India \\ *Email: suman2013mech@ gmail.com \\ ${ }^{2}$ Mechanical Engineering Department, National Institute of Technology Agartala, \\ 799046, India
}

\begin{abstract}
The issue of environmental pollution and the depletion of fossil fuel are nowadays a major field of attention for the modern world. In substitution of petroleum-based diesel, biodiesel and ethanol have been explored in many studies. In this paper, diesel-palm biodiesel-ethanol has been used together at different proportion to execute performanceemission characteristics and their trade-off study at different brake power. An experimental investigation is carried out for different diesel-palm biodiesel-ethanol blends ranging by volume of 5-10\% ethanol, 5-25\% biodiesel and 65-90\% baseline diesel. From the experimental results, comparatively, low brake specific fuel consumption (BSEC) has been observed for all 5\% ethanol-blended fuels. Maximum reduction in BSEC has been observed $1.9,2$, and $3.24 \%$ at $0.68,2.05$, and $3.42 \mathrm{~kW}$ respectively. At medium to high load, brake thermal efficiency (BTE) has been found higher for lower ethanol fraction. As compared to diesel, the highest nitrogen oxide (NOx) reduction have been found 13.7, 9.17, and $4.7 \%$ at $0.68,2.05$, and $3.42 \mathrm{~kW}$ respectively. At last, performance-emission trade-off shows that D70B25E5 blend has a higher BTE with maximum reduction in unburnt hydrocarbon (UHC) and NOx emissions.
\end{abstract}

Keywords: Alternative energy; blend preparation; performance-emission; NOx-BSECBTE trade-off; NOx-UHC-BTE trade-off.

\section{NOMENCLATURE}

\begin{tabular}{|c|c|c|c|}
\hline $\mathrm{CO}$ & carbon monoxide & DAQ & data acquisition \\
\hline ITE & $\begin{array}{l}\text { indicated thermal } \\
\text { efficiency }\end{array}$ & $\mathrm{DE}$ & diesel ethanol \\
\hline $\mathrm{BE}$ & biodiesel ethanol & VCR & variable compression ratio \\
\hline BTE & brake thermal efficiency & GUI & graphical user interphase \\
\hline NOx & nitrogen oxides & HRR & heat release rate \\
\hline MME & mahua methyl ester & BSNOx & $\begin{array}{l}\text { brake specific oxides of } \\
\text { nitrogen }\end{array}$ \\
\hline UHC & unburned hydrocarbon & D100 & $100 \%$ diesel \\
\hline BSFC & $\begin{array}{l}\text { brake specific fuel } \\
\text { consumption }(\mathrm{kg} / \mathrm{kW}-\mathrm{h})\end{array}$ & D90B5E5 & $\begin{array}{l}90 \% \text { diesel+5\% } \\
\text { biodiesel+5\%ethanol }\end{array}$ \\
\hline BSEC & $\begin{array}{l}\text { brake specific energy } \\
\text { consumption }(\mathrm{kJ} / \mathrm{kW}-\mathrm{h})\end{array}$ & D85B10E5 & $\begin{array}{l}85 \% \text { diesel+10\% } \\
\text { biodiesel+5\% ethanol }\end{array}$ \\
\hline
\end{tabular}




$\begin{array}{llcl}\text { D80B10E10 } & \begin{array}{l}80 \% \text { diesel+10\% } \\ \text { biodiesel+10\%ethanol }\end{array} & \text { D80B15E5 } & \begin{array}{l}80 \% \text { diesel+15\% } \\ \text { biodiesel+5\%ethanol }\end{array} \\ \text { D75B15E10 } & \begin{array}{l}75 \% \text { diesel+15\% } \\ \text { biodiesel+10\%ethanol }\end{array} & \text { D75B20E5 } & \begin{array}{l}75 \% \text { diesel+20\% } \\ \text { biodiesel+5\%ethanol }\end{array} \\ \text { D70B20E10 } & \begin{array}{l}70 \% \text { diesel+20\% } \\ \text { biodiesel+10\%ethanol }\end{array} & \text { D70B25E5 } & \begin{array}{l}70 \% \text { diesel+25\% } \\ \text { biodiesel+5\%ethanol }\end{array} \\ \text { D65B25E10 } & \begin{array}{l}65 \% \text { diesel+25\% } \\ \text { biodiesel+10\%ethanol }\end{array} & \text { D85B5E10 } & \begin{array}{l}85 \% \text { diesel+5\% } \\ \text { biodiesel+10\%ethanol }\end{array}\end{array}$

\section{INTRODUCTION}

The rapid rise in crude oil price due to its vast application in factory, transportation, agriculture etc. have been increasing day by day. Most of the modern engine works on diesel operation where the application of diesel in transportation has recorded the highest emissions. The ever-increasing concern of environment pollution is mainly due to the dreadful level of greenhouse gas emissions worldwide [1]. Among all the greenhouse gas emissions, NOx and particulate matter (PM) are more predominant in environment pollution. Now, most of the countries have transformed their thought towards alternative energy resources where animal fat, vegetable oil-based biodiesel and alcohol play a vital role. Moreover individually biodiesel or alcohol cannot perform effectively due to their poor physiochemical property [2]. Due to poor properties, lubricating oil in biodiesel fuelled engine has faced an increase in density, carbon residue and ash content with the usage [3]. Experimentally it has been found that biodiesel containing free fatty acid when mixed with diethyl ether has improved acid value, heating value and pour point [4]. Transesterification [5] is a technique for high viscous biodiesel to prevent problems like formation of carbon deposits in the combustion chamber, fuel filter plugging, injector coking, ring sticking and contamination of lubricating oil [6] etc.

Diesel fuel replaced by Jatropha, Moringa and Palm biodiesel up to $20 \%$ based on ASTM D6751 standard has improved performance and emissions without any engine modification [7]. Blending of alternative fuels in the form of diesel-ethanol, biodieselethanol or diesel-biodiesel-ethanol is environment-friendly and less toxic [8][9][10][11]. Also, long-chain alcohol like pentanol when mixed with diesel can improve the thermophysical property of the blend. Superior combustion due to enriched oxygen in diesel-pentanol blend improves BSFC (brake specific fuel consumption) and BTE [12]. Higher BTE has been found for ethanol-diesel blend compared to base diesel. BTE also increases at all load condition due to the addition of cetane number improver that helps further to reduce NOx and smoke emission [13]. However, to produce optimum performance-emissions of the engine appropriate mixture of the additive is the key concern [14]. High oxygen content biodiesel of poor cold flow property, high density and pour point create a barrier while performing in cold weather condition. Ethanol or diethyl ether is one of the substitutes to meet the desired properties of biodiesel for use in the diesel engine. Addition of ethanol in palm biodiesel-diesel blend enhanced kinematic viscosity, cloud and pour point of the blend [15]. Ethanol commonly known as alcohol produced from sugarcane, corn, sugar beet, molasses etc. helps in reduction of PM emission due to the presence of high oxygen molecules [16][17]. Experimentally it has been found that with increasing ethanol fraction in the ethanol-biodiesel blend, pressure and heat release rate (HRR) increases. Also due to the higher latent heat of vaporisation of ethanol, BSNOx (brake specific nitrogen oxides) emission decreases [18]. 
Experiment on naturally aspirated, 4-cylinder direct-injection diesel engine using ultralow sulfur diesel as base fuel with biodiesel and ethanol as an additive improved BTE. High oxygen content in additive reduces both HC (hydrocarbon) and CO (carbon monoxide) emissions compared to base diesel whereas NOx emission increases [19]. At different advanced injection timing, as ethanol fraction increases on a biodiesel-ethanol blend, NOx emission decreases at medium to high load. Due to the low heating value of ethanol, as percentage addition increases, it increases ignition delay that results in lower peak cylinder pressure and temperature [20]. High viscosity Mahua Methyl Ester (MME), when blended with ethanol, improves the cold flow property of the blend. High latent heat of vaporisation of ethanol also reduced combustion temperature that helps in lowering the NOx emission. Also, prolonged ignition timing due to ethanol helps to reduce smoke emission [21]. The addition of ethanol in biodiesel blended diesel fuel increased HC emission with the increase in ethanol fraction. It has been observed that with the increase in ethanol percentage, the total cetane number of the blend decreases. Slow vaporisation and poor oxidation reaction retard the combustion that results in high $\mathrm{HC}$ emission [22]. Study of performance and emissions of a diesel engine at different ethanol fraction where diesel-ethanol blend performed maximum indicated thermal efficiency (ITE) of 35\% compared to biodiesel-ethanol blend. Increase in NOx emission with the increase in ethanol is higher in diesel-ethanol (DE) blend than that of biodiesel-ethanol (BE) however $\mathrm{CO}$ emission decreases for both blends [23].

\section{Motivation and Objective}

Universal currency handled by energy is the main origin of our everyday life necessity. Development of sustainable society by renewable energy phasing referred from the paradigm shift of fossil fuel energy. To support the future energy crisis and high environmental emission, alternative fuel for diesel engine has to be taken care off. There should be required enormous effort in the field of automotive research for more and more green combustion. In the prospect of diesel fuel emission norms, renewable resources like biodiesel or other additives containing oxygenated property can be an effective alternative. The present study provides an interpretive overview of palm biodiesel application on performance-emission characteristics to meet forthcoming challenges in the diesel engine. Palm oil with large oil yield of 4 to 5 tons of oil/ha annually, is ten times higher than soybean, sunflower or rapeseed oil. Easy availability and 20-30\% lower production cost compared to other vegetable oils make it the most advantageous alternative to diesel. This paper explains the potential of combined ethanol and palm biodiesel on performance and emissions of single-cylinder 4-stroke diesel engine. This paper also presents NOx-BSEC-BTE and NOx-UHC-BTE trade-off challenges in order to show overall improved performance-emissions synergy by the penalty of any of the emission mandates.

\section{EXPERIMENTAL METHODOLOGY}

The experimental investigation is performed at a constant speed $(1500 \mathrm{rpm})$ in a single cylinder 4 strokes, water-cooled, VCR direct injection diesel engine coupled with eddy current dynamometer. The schematic diagram and specification of the engine are shown in Figure 1 and Table 1 respectively. NI Labview ${ }^{\circledR}$ based centralised DAQ is connected to the engine via a computer system which is synchronized with a crank angle encoder onto a GUI based Engine Soft post-processing software. At every 1-degree crank interval, 
in-cylinder pressure and fuel injection pressure data are measured in DAQ by a piezoelectric pressure sensor (make Kistler). The specific fuel consumption is carried out in fuel burette for a time interval of $60 \mathrm{sec}$. Air mass flow rate has been calculated by manometric depression integrated into the airbox. A 5-gas analyser (Make: AVL India, Model: 444) with DiGas sampler (Table 2) is fitted at the exhaust pipe to measure the emission of $\mathrm{CO}$, carbon dioxide (CO2), oxygen (O2), NOx and UHC. The gas analyser has been calibrated before each measurement using reference gases to make sure the accuracy of the measured values. For all settings, the emission values and the other values are recorded twice and a mean of these is taken for comparison. The average ambient temperature, cooling water temperature and relative humidity during experimentation is recorded at $25^{\circ} \mathrm{C}, 18^{\circ} \mathrm{C}$, and $55 \%$, respectively.

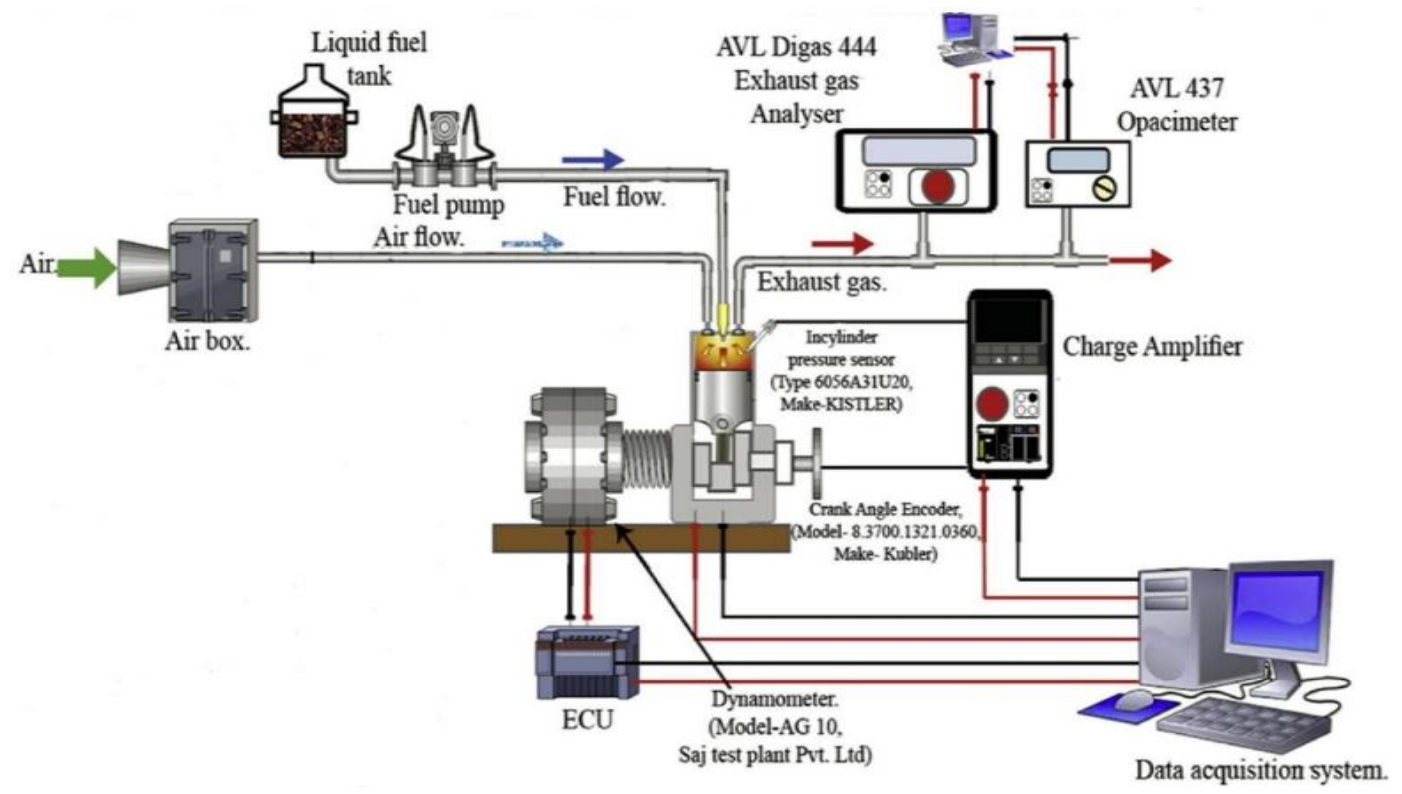

Figure 1. Schematic diagram of the test engine.

Table 1. Specification of the engine.

\begin{tabular}{lcc}
\hline Serial no. & Parameters & Specification \\
\hline 1 & General details & $\begin{array}{c}\text { Single cylinder, VCR, 4 stroke, CI engine, } \\
\text { vertical, water-cooled, constant speed, direct } \\
\text { injection }\end{array}$ \\
2 & Stroke & $110 \mathrm{~mm}$ \\
3 & Bore & $87.5 \mathrm{~mm}$ \\
4 & Displacement & $661 \mathrm{cc}$ \\
5 & Compression ratio & 17.5 \\
6 & Rated output & $3.5 \mathrm{~kW}$ \\
7 & Rated speed & $1500 \mathrm{rpm}$ \\
8 & Fuel injection pressure & $220 \mathrm{bar}$ \\
\hline
\end{tabular}

\section{Data Uncertainty Analysis}

Experimental uncertainty analysis is a technique to identify and quantify error during the measurement of emission and the obtained engine performance parameter on account of 
calibration and utilization of employed instruments, the accuracy of observation and the methodology adopted during experimentation in a given ambient condition. The uncertainty analysis has two main components namely, bias related to accuracy and random variation that occurs during repeated measurements. In this present study, the experimental error analysis which has already been detailed in communication made by the authors in earlier manuscripts [24][25].

Table 2. Accuracy of the emission measuring instrument (AVL DIGAS 444-5 gas analyser) [24].

\begin{tabular}{|c|c|c|c|c|c|}
\hline $\begin{array}{l}\text { Measured } \\
\text { parameter }\end{array}$ & $\begin{array}{l}\text { Measurement } \\
\text { principle }\end{array}$ & $\begin{array}{l}\text { Measuring } \\
\text { range }\end{array}$ & Resolution & Accuracy & $\begin{array}{l}\text { \%uncertainty } \\
\text { in sampling }\end{array}$ \\
\hline $\mathrm{CO}$ & NDIR & $0 \ldots 10 \%$ vol & $0.01 \%$ vol & $\begin{array}{c}<0.6 \% \text { vol: } \\
\pm 0.03 \% \text { vol. } \\
\geq 0.6 \% \text { vol.: } \\
\pm 5 \% \text { of } \\
\quad \text { value }\end{array}$ & $\begin{array}{l} \pm 0.2 \\
\pm 0.3\end{array}$ \\
\hline $\mathrm{CO} 2$ & NDIR & $0 \ldots 20 \%$ vol. & $0.1 \%$ vol. & $\begin{array}{c}<10 \% \text { vol.: } \\
\pm 0.5 \% \text { vol. } \\
\geq 10 \% \text { vol.: } \\
\pm 5 \% \text { of } \\
\quad \text { value }\end{array}$ & $\begin{array}{l} \pm 0.15 \\
\pm 0.2\end{array}$ \\
\hline $\begin{array}{l}\text { total } \\
\text { unburnt } \\
\text { hydro } \\
\text { carbons } \\
\text { (TUHC) }\end{array}$ & NDIR & $\begin{array}{l}0 \ldots 20,000 \\
\text { ppm vol. (n- } \\
\text { hexane } \\
\text { equivalent) }\end{array}$ & $\begin{array}{l}\leq 2000: 1 \\
\text { ppm vol. } \\
>2000: 10 \\
\text { ppm vol. }\end{array}$ & $\begin{array}{c}<200 \mathrm{ppm} \\
\text { vol.: } \pm 10 \\
\text { ppm. } \\
\geq 200 \mathrm{ppm} \\
\text { vol.: } \pm 5 \% \\
\text { of value }\end{array}$ & $\begin{array}{l} \pm 0.1 \\
\pm 0.2\end{array}$ \\
\hline $\mathrm{O} 2$ & $\begin{array}{l}\text { Electro } \\
\text { chemical } \\
\text { sensor }\end{array}$ & $0 \ldots .22 \%$ vol & $0.01 \%$ vol. & $\begin{array}{c}<2 \% \text { vol.: } \\
\pm 0.1 \% \text { vol } \\
\geq 2 \% \text { vol.: } \\
\pm 5 \% \text { of } \\
\text { value. }\end{array}$ & $\begin{array}{l} \pm 0.2 \\
\pm 0.3\end{array}$ \\
\hline $\begin{array}{l}\text { Nitric } \\
\text { oxide (NO) }\end{array}$ & $\begin{array}{l}\text { Electro } \\
\text { chemical } \\
\text { sensor }\end{array}$ & $\begin{array}{c}0 \ldots 5000 \mathrm{ppm} \\
\text { vol. }\end{array}$ & 1 ppm vol. & $\begin{array}{c}<500 \mathrm{ppm} \\
\text { vol.: } \pm 50 \\
\text { ppm vol. } \\
\geq 500 \mathrm{ppm} \\
\text { vol.: } \pm 10 \% \\
\text { of value }\end{array}$ & $\begin{array}{l} \pm 0.2 \\
\pm 0.9\end{array}$ \\
\hline $\begin{array}{l}\text { Lambda } \\
\text { Warm } \\
\text { uptime }\end{array}$ & & $\begin{array}{l}0 \ldots 9.999 \\
\approx 7 \mathrm{~min}\end{array}$ & 0.001 & & \\
\hline $\begin{array}{l}\text { Response } \\
\text { time }\end{array}$ & & $\leq 15 \mathrm{~s}$ & & & \\
\hline $\begin{array}{l}\text { Relative } \\
\text { humidity } \\
\text { PC } \\
\text { Interfaces }\end{array}$ & & $\begin{array}{l}\leq 95 \% \text { non- } \\
\text { condensing } \\
\text { RS232C }\end{array}$ & & & \\
\hline
\end{tabular}




\section{Preparation of Test Fuel}

In this present study, diesel, palm biodiesel, and ethanol blend are used for the performance-emissions test of a diesel engine. The properties of test fuel are shown in Table 3. Diesel is blended with palm biodiesel and ethanol to obtain a ternary blend of different proportion. Preparation of blend is made for 5\% and $10 \%$ volume of ethanol. Biodiesel is mixed 5, 10, 15, 20 and 25\% in volume and subsequent diesel. The prepared blend is denoted by D90B5E5 where D, B, and E denotes diesel, biodiesel, and ethanol and the subsequent number shows their respective volume in percentage. To find the miscibility of ethanol, it has been mixed at different proportion with diesel and palm biodiesel is shown in Figure 2. After keeping all the blends under complete observation for 30 days, the stability of samples is examined. It has been observed from Figure 2 that $5 \%$ and $10 \%$ ethanol with $95 \%$ and $90 \%$ diesel were partially non-miscible. Considering the stability of ethanol, D90B5E5, D85B10E5, D80B15E5, D75B20E5, D70B25E5, D85B5E10, D80B10E10, D75B15E10, D70B20E10 and D65B25E10 are selected for the engine test. Using D100 and ten different ternary blends, performance and emissions analysis is carried out for three different brake power (i.e. $0.68,2.05$ and $3.42 \mathrm{~kW}$ ). At the end, performance-emission trade-off between NOx-BSEC-BTE and NOx-UHC-BTE have been explained. During the experiment, the engine is allowed to run for 10-15 minutes to come to its original working condition. For the consideration of final data of each experimental fuel, an average of six consecutive reading is taken.

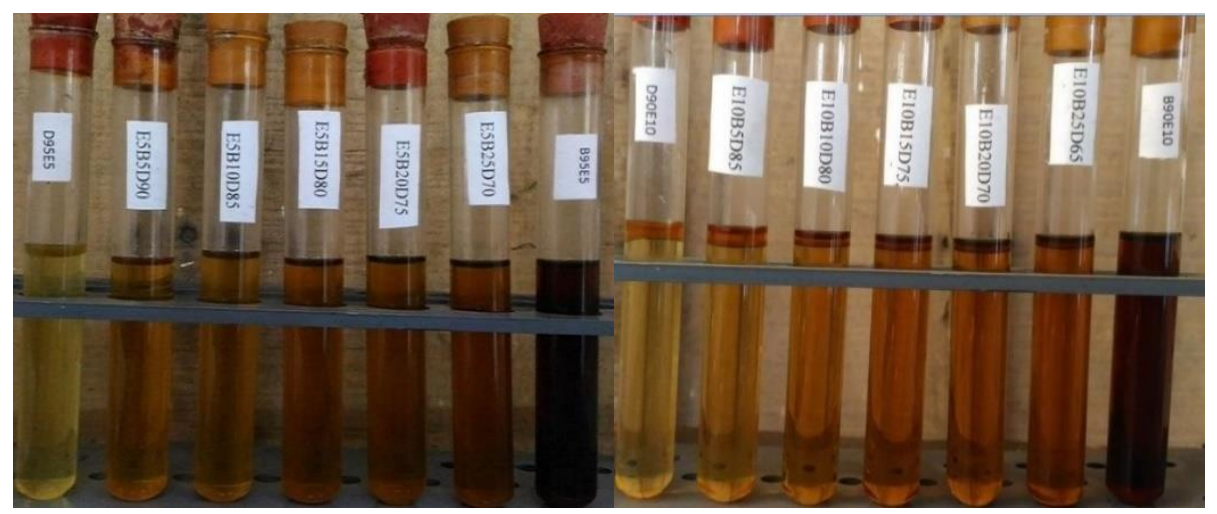

Figure 2. Fuel blends after 30 days.

Table 3. Properties of fuel.

\begin{tabular}{lllllll}
\hline & $\begin{array}{l}\text { Density at } \\
\text { 200C } \\
(\mathrm{kg} / \mathrm{m} 3)\end{array}$ & $\begin{array}{l}\text { Cetane } \\
\text { number }\end{array}$ & $\begin{array}{l}\text { Kinematic } \\
\text { viscosity at } \\
\text { NTP }(\mathrm{cSt})\end{array}$ & $\begin{array}{l}\text { Oxygen } \\
\text { content } \\
(\mathrm{wt} \%)\end{array}$ & $\begin{array}{l}\text { Calorific } \\
\text { value } \\
(\mathrm{kJ} / \mathrm{kg})\end{array}$ & $\begin{array}{l}\text { Flash } \\
\text { point } \\
\left({ }^{\circ} \mathrm{C}\right)\end{array}$ \\
\hline $\begin{array}{l}\text { Diesel } \\
\text { Palm }\end{array}$ & 836 & 49 & 2.45 & 0 & 42800 & 100 \\
$\begin{array}{l}\text { Biodiesel } \\
\text { Ethanol }\end{array}$ & 925 & 62 & 4.56 & 11.2 & 39849 & 167 \\
\hline
\end{tabular}




\section{RESULTS AND DISCUSSION}

\section{Brake Thermal Efficiency}

BTE is the evaluation of how well an engine can convert fuel energy into mechanical energy. Figure 3(a)-3(c) show change in BTE at different brake power (BP). It has been found that with increasing BP, BTE increases for all test fuels. Maximum BTE of 10.52, 14.96 and $19.48 \%$ has been observed at $0.68,2.05$ and $3.42 \mathrm{~kW}$ load for D85B5E10, D90B5E5 and D75B20E5 blend respectively. It can be explained that high oxygen participation and superior mixing enhanced combustion performance that leads to maximum BTE for D85B5E10, D90B5E5 and D75B20E5. At 0.68, 2.05, and $3.42 \mathrm{~kW}$ brake power, BTE increases 2.33, 1.8, and $2.4 \%$ for D85B5E10, D90B5E5 and D75B20E5 respectively. It has also been observed that if ethanol percentage increases from 5 to 10\%, BTE decreases for all load condition. Among all blend, D90B5E5 shows almost equal BTE as compared to diesel at all load condition. Ethanol has high oxygen content, but low cetane number and heating value. Due to the low cetane value of ethanol, the overall cetane number of the blend decreases. It further decreases the combustion performance that results in low overall thermal efficiency compared to diesel [19].

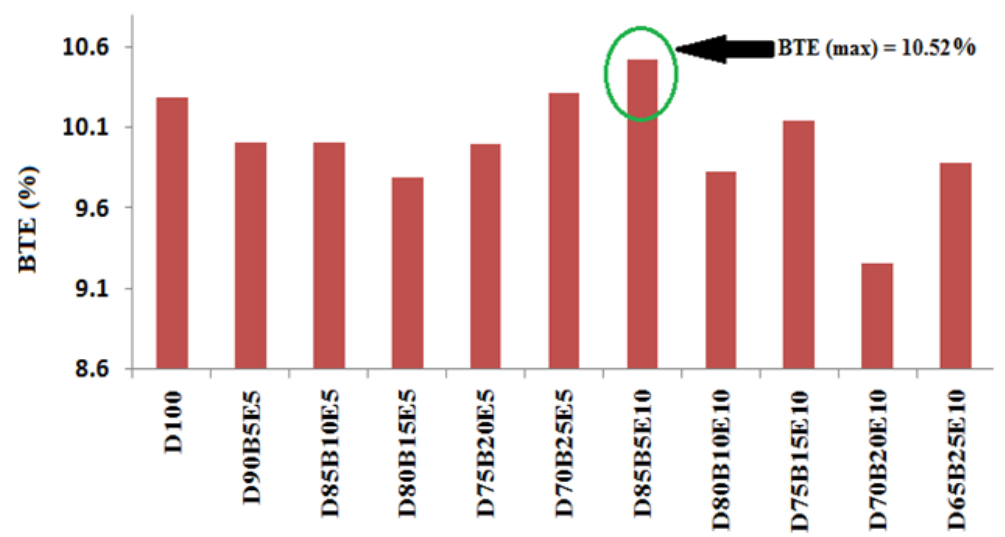

(a) $0.68 \mathrm{~kW}$

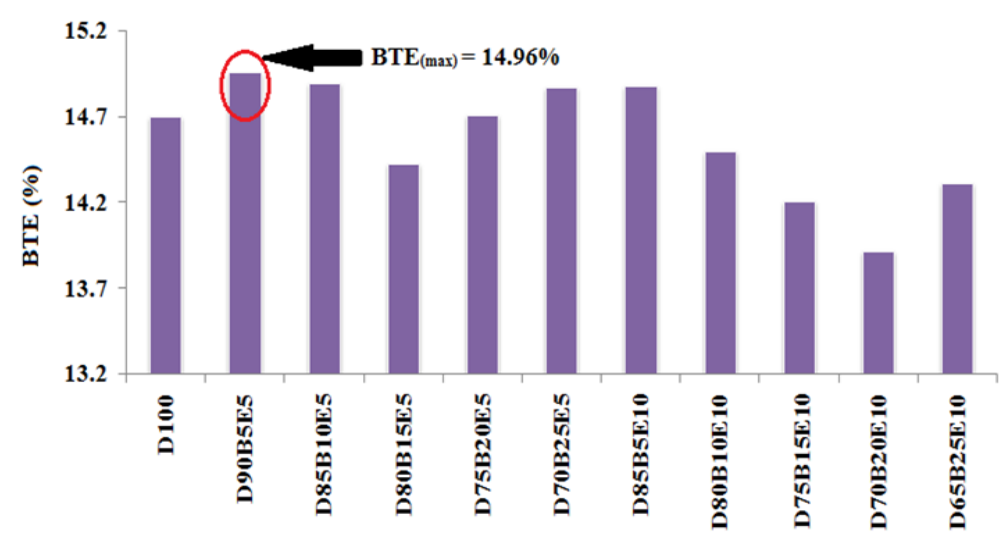

(b) $2.05 \mathrm{~kW}$ 


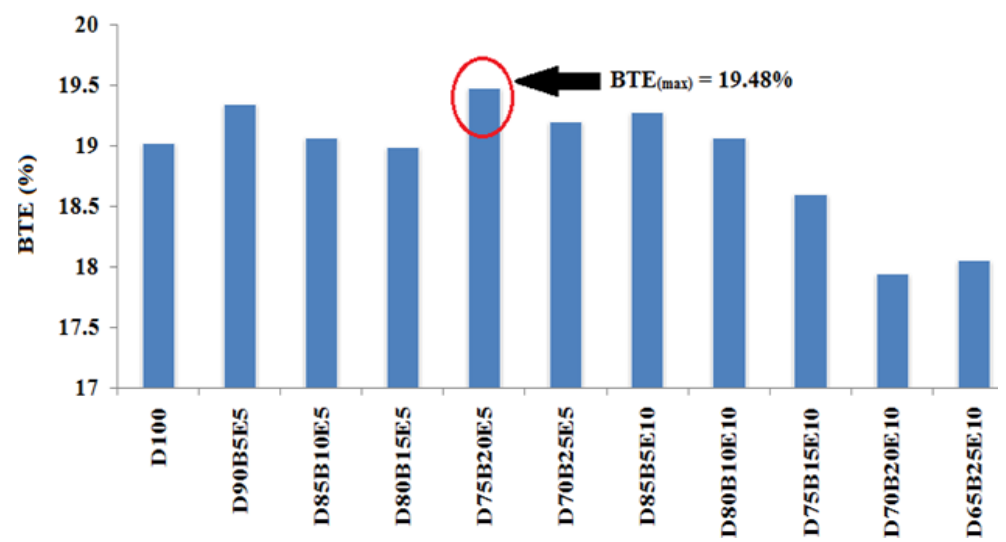

(c) $3.42 \mathrm{~kW}$

Figures 3. BTE at different brake power.

\section{Brake Specific Fuel Consumption}

BSEC implies the efficiency of fuel energy which is effective during combustion for engine output. Figure 4(a)-4(c) depict the variation of BSEC $(\mathrm{kJ} / \mathrm{kW}-\mathrm{h})$ with brake power for all test fuels, where, as brake power increased BSEC of fuel decreases. Lowest BSEC at $0.68,2.05$ and $3.42 \mathrm{~kW}$ brake power have been found for D85B5E10, D90B5E5 and D75B20E5 blend respectively. The lowest BSEC at 0.68, 2.05, and $3.42 \mathrm{~kW}$ are marked in Figure 4(a)-4(c) which is 1.9, 2, and 3.24 \% lower compared to base diesel. It has also been observed that D70B20E10 blend shows maximum BSEC at all braking power. This can be explained that if biodiesel percentage increased the viscosity of blend increases, due to which more fuel has to be injected into the cylinder [26]. Also, low density and low heating value of ethanol enhanced the faster burning rate of blended fuel that increased BSEC to produce the same brake power [27]. At low brake power, BSEC increases due to the low heating value of ethanol. However, with an increase in load, combustion efficiency has been improved and for that BSEC decreases [8].

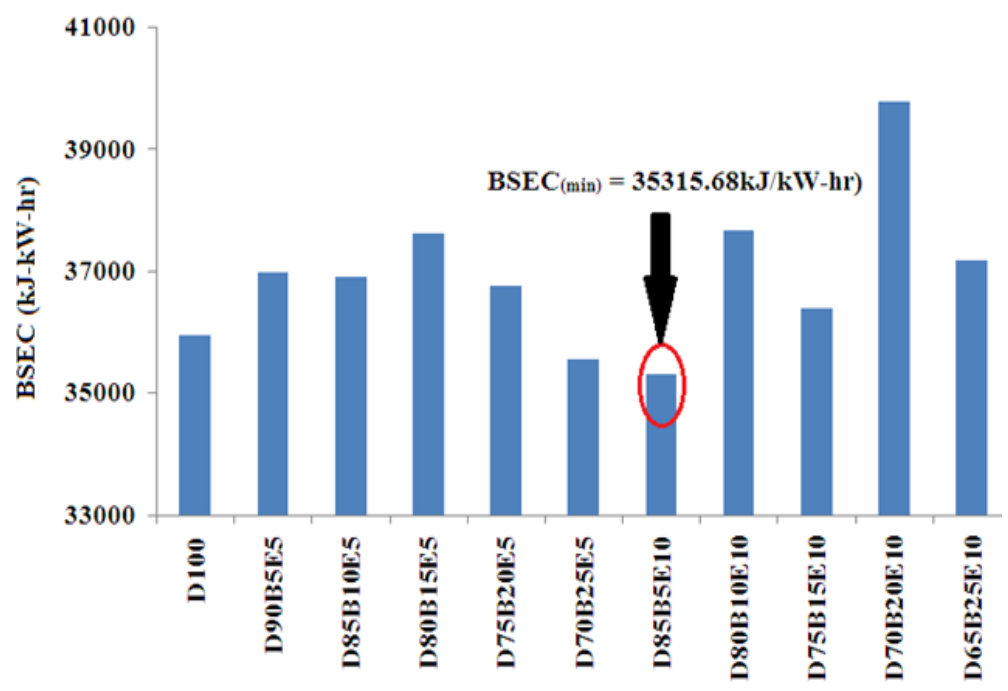

(a) $0.68 \mathrm{~kW}$ 


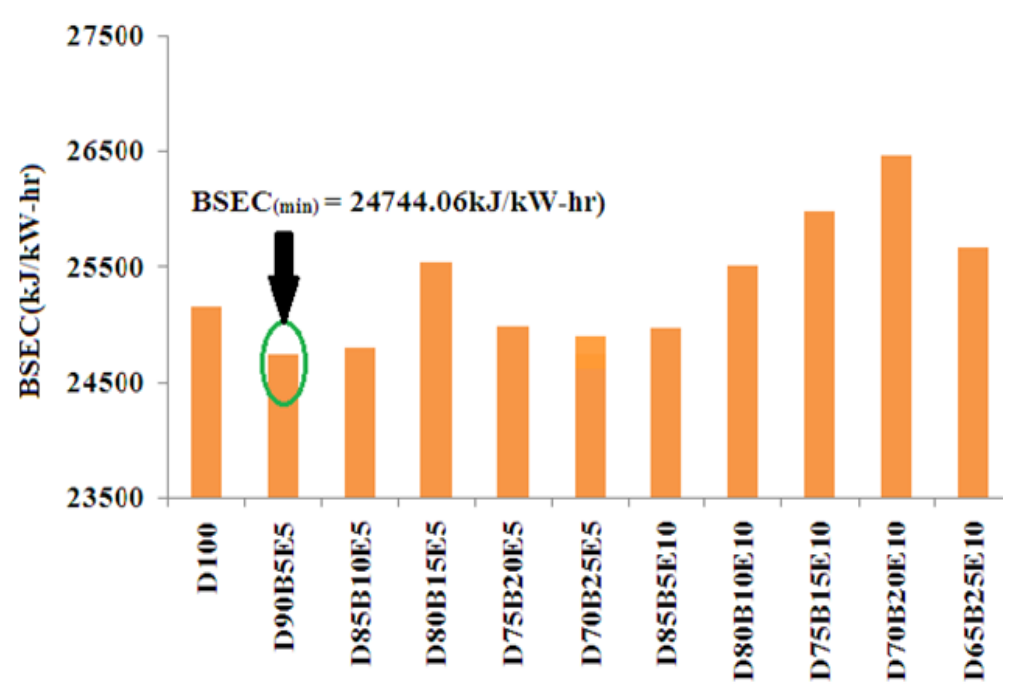

(b) $2.05 \mathrm{~kW}$

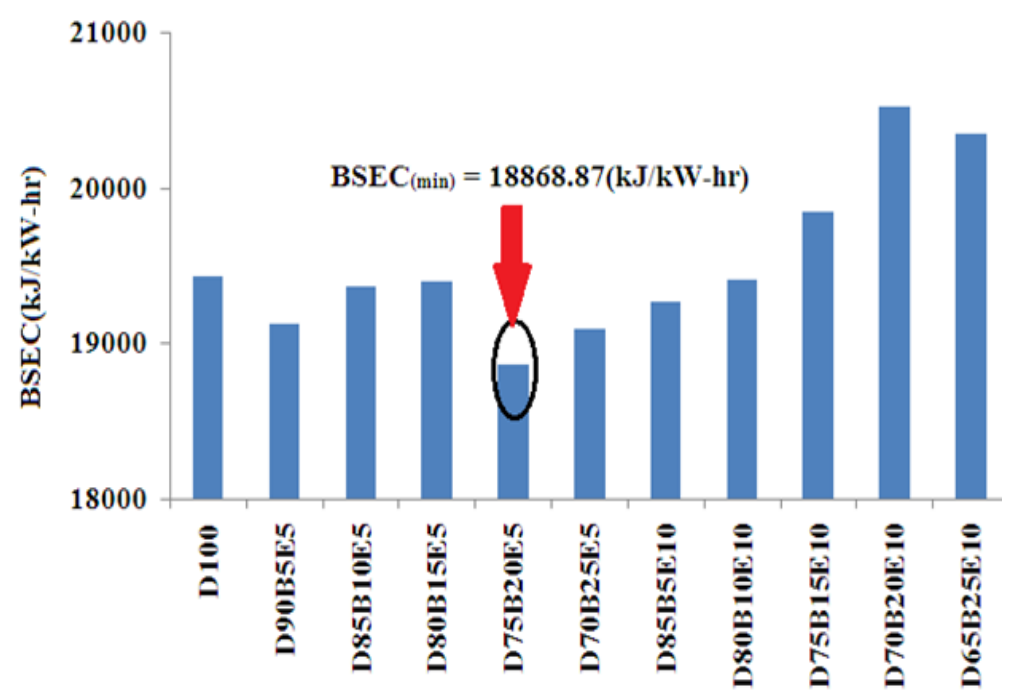

(c) $3.42 \mathrm{~kW}$

Figures 4. BSEC at different brake power.

\section{Nitrogen Oxides Emission}

The variation of NOx at different brake power is illustrated in Figures 5(a)-(c) for different blends and diesel. The results show that the NOx emission for all blends is almost similar to diesel and increase in a linear fashion with an increase in brake power. A maximum reduction in NOx emission of 13.7, 9.17, and $4.7 \%$ are observed at 0.68 , 2.05, and $3.42 \mathrm{~kW}$ brake power for D90B5E5, D75B20E5, and D70B20E10 blend respectively. At higher brake power, the increase in NOx emission is caused due to hightemperature generation during the combustion. Maximum NOx emission for medium and high BP has been found for E10B5D85 blend. Because of low heat generation at low load, there is no such change in NOx emission for all test fuels. At medium to high load, NOx emission increases due to oxygen content in both biodiesel and ethanol that enhances the high combustion temperature. However, the relative increase in NOx emission is comparatively low at high load due to the better oxidation of nitrogen during combustion. Ignition delay has increased due to lower cetane value of ethanol which further increases 
the premixed combustion duration and premixed combustion temperature. It has also been noticed that with the increase in ethanol fraction from 5 to $10 \%$, NOx emission increases more at medium to high load.

\section{Unburnt Hydrocarbon Emission}

Partial combustion of fuel inside the combustion chamber is the main cause of the unburnt hydrocarbon emission. The variations of UHC emission with brake power for the dieselpalm biodiesel-ethanol ternary blend are compared in Figures 5(a)-5(c). It is found that among all ternary blend D70B20E5 shows lowest UHC emission. It has been observed that as brake power increases UHC emission increases for all test fuel, however for diesel it is lower compared to all other blends. An increase in 17, 42.9 and $24 \%$ UHC emission have been observed for D70B25E5, D75B20E5, and D80B15E5 respectively which is lowest compared to other blends. It is because of the incomplete combustion of the blends which is mainly due to the lower cetane number of ethanol [13]. It is also observed that as ethanol addition increases from 5 to $10 \%$, the tendency of UHC emission also increases.

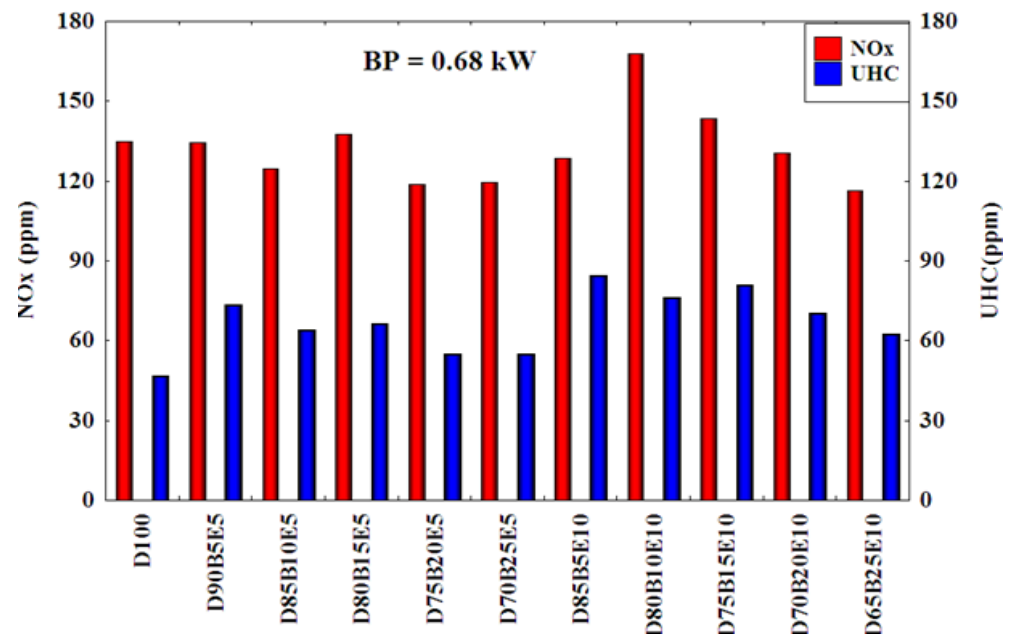

(a) $0.68 \mathrm{~kW}$

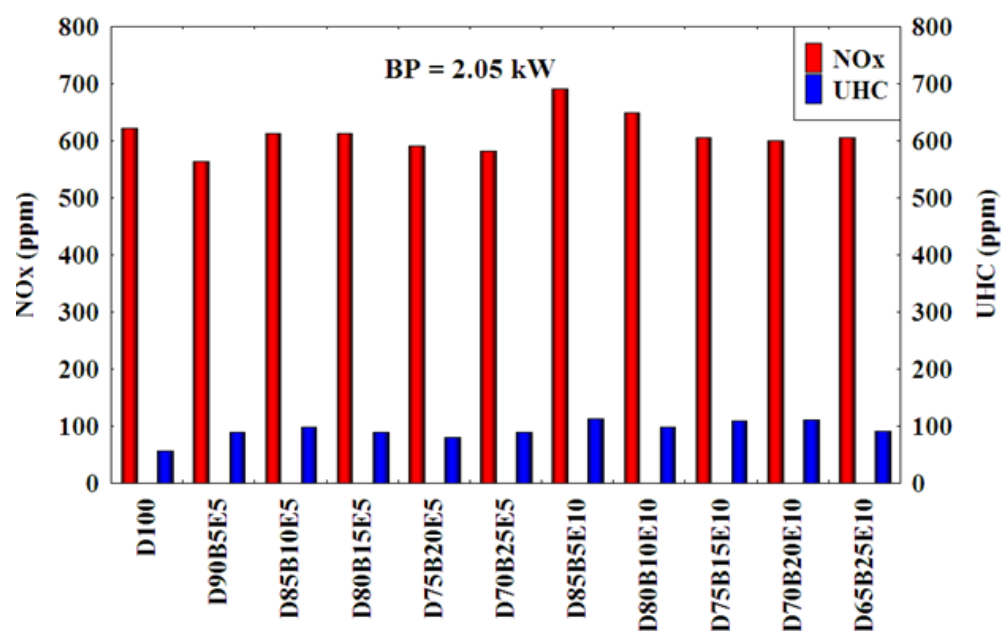

(b) $2.05 \mathrm{~kW}$ 


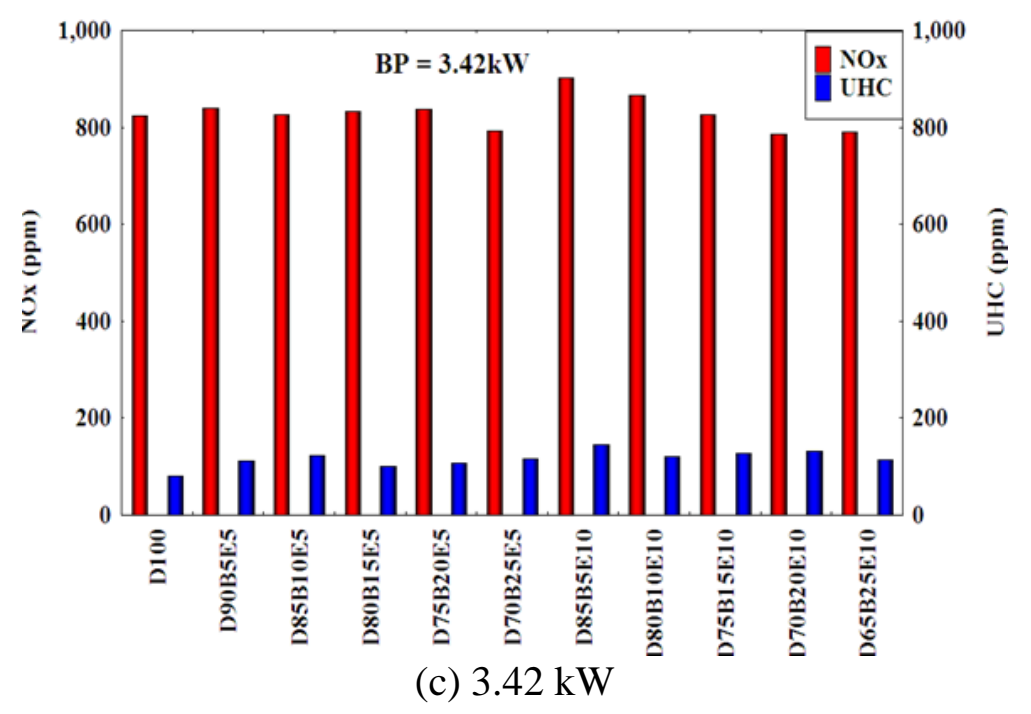

Figures 5. Variation of NOx and UHC emissions at different brake power.

\section{Trade-Off Study}

Parallel success to the performance improvement and emissions reduction in a diesel engine is always a challenging situation. In reduction to a particular emission may lead to an increase in other emissions. In such circumstances, trade-off study between performance and emission parameters may lower the difficulties during the decision making. In this study, performance-emission trade-off between NOx-BSEC-BTE and NOx-UHC-BTE have been carried out to identify optimum ternary blend for maximum possible BTE and minimum emissions. From Figure 6(a), at $0.68 \mathrm{~kW}$ brake power, with the increase in biodiesel fraction and 5\% ethanol, NOx emission decreases. As ethanol increases from 5 to $10 \%$, NOx emission again decreases with the increase of biodiesel addition with some penalty to BTE. The trend of increase in BTE has been observed at Zone A for blend D70B25E5 with some increase in NOx emission.

It has been noticed from trade-off at $2.05 \mathrm{~kW}$ (in Figure 6(b)) that BTE decreases for $10 \%$ ethanol fraction as compared to 5\% ethanol. Among all blend, D85B5E10 and D75B20E5 exhibit more NOx emission which has shifted trade-off zone towards Zone B. As compared to D100, operation with D70B25E5 and D90B5E5 decrease both BSEC and NOx emission with no such change in BTE. From the trade-off, at $2.05 \mathrm{~kW}$ it has been observed that $5 \%$ ethanol fraction is much better to reduce BSEC and NOx emission with aid in higher BTE. From performance-emission tradeoff in Figure 6(c) at $3.42 \mathrm{~kW}$ brake power, it can be easily explained that contribution of $5 \%$ ethanol fraction is more effective to reduce BSEC with significantly higher BTE compared to $10 \%$ ethanol addition. Among all blend, D85B5E10 blend operation introduces more NOx emission which is shown in Zone $\mathrm{C}$. 


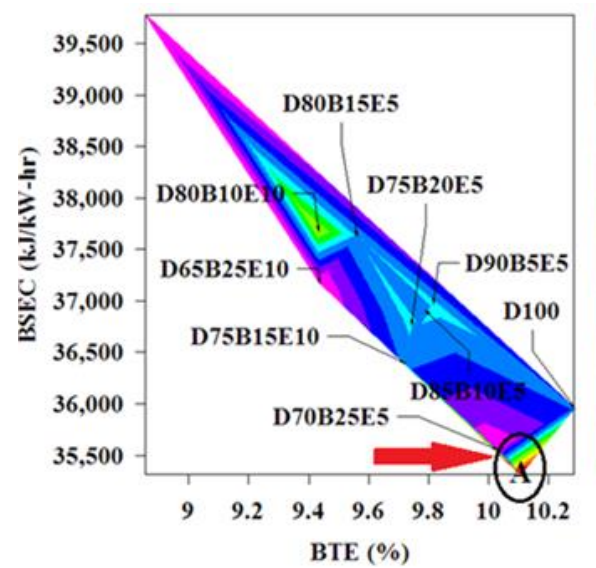

(a) $0.68 \mathrm{~kW}$

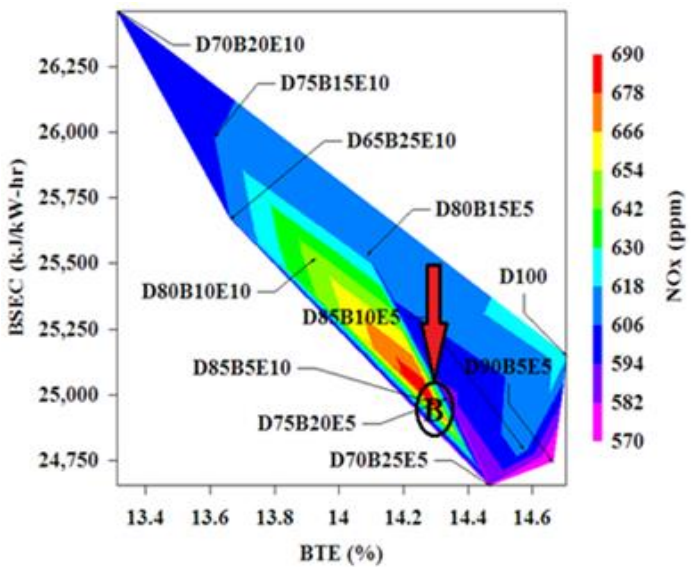

(b) $2.05 \mathrm{~kW}$

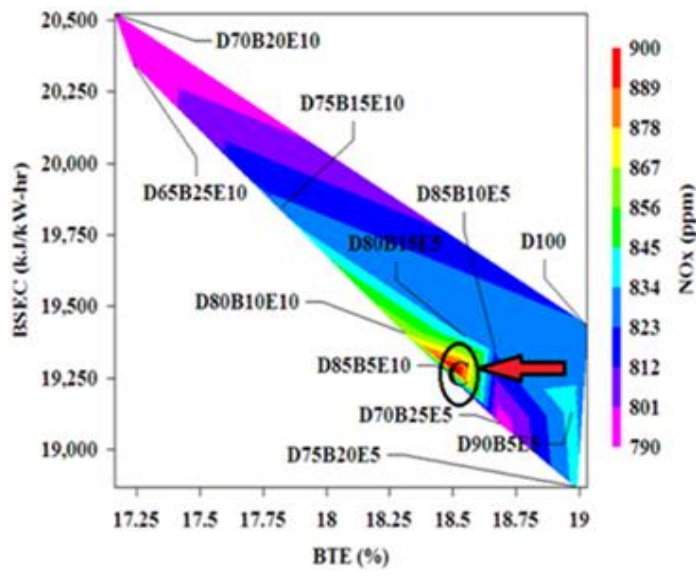

(c) $3.42 \mathrm{~kW}$

Figure 6. NOx-BSEC-BTE trade-off at different brake power.

In Figure 7(a)-7(c) the trade-off study of NOx-UHC-BTE at three different brake power has been shown. It can be easily explained that ternary blend with $10 \%$ ethanol fraction is more prone in formation of NOx and UHC emissions which is shown in Zone D. Similar type of comprehensive idea have been illustrated by Majumder et al. [28] for performance-emission trade-off at a time. It has been clearly noticed from Figure 7(a) that D70B25E5 performs better in the highest reduction in UHC emission whereas D80B10E10 shows maximum NOx emission. At $2.05 \mathrm{~kW}$ brake power with $5 \%$ ethanol share, BTE increases with lower NOx emissions. There is no such improvement in UHC emission except D100, where 10\% ethanol share represent maximum UHC emission which shifted trade-off in Zone E. From Figure 7(b), it has been observed that ternary blend with 5\% ethanol share performs at higher BTE compared to 10\% ethanol fraction. Such inherent challenges of performance-emission dilemma have been greatly reinforced and amplified by Banerjee et al. [29] for the new diesel engine operational paradigms. At $3.42 \mathrm{~kW}$ brake power, the maximum penalty in NOx and UHC emissions have been found for D85B5E10 blend is shown in Zone F (in Figure 7(c)). 


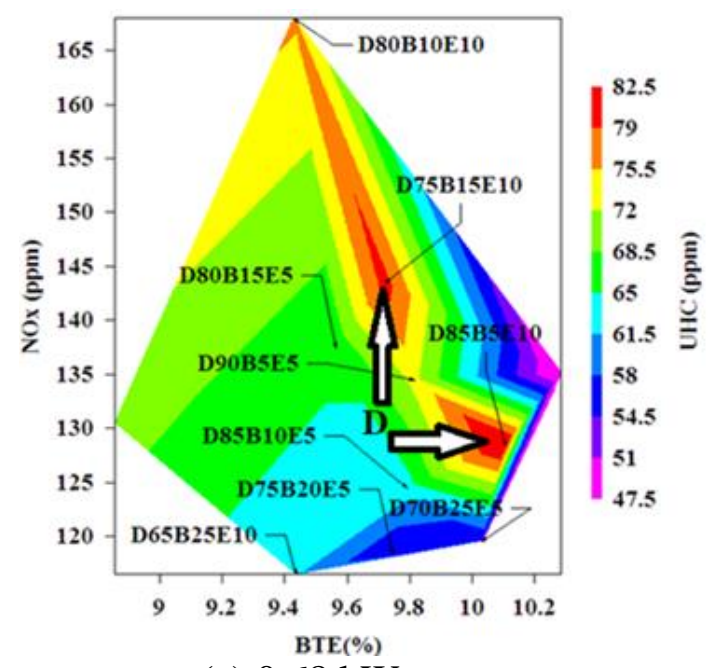

(a) $0.68 \mathrm{~kW}$

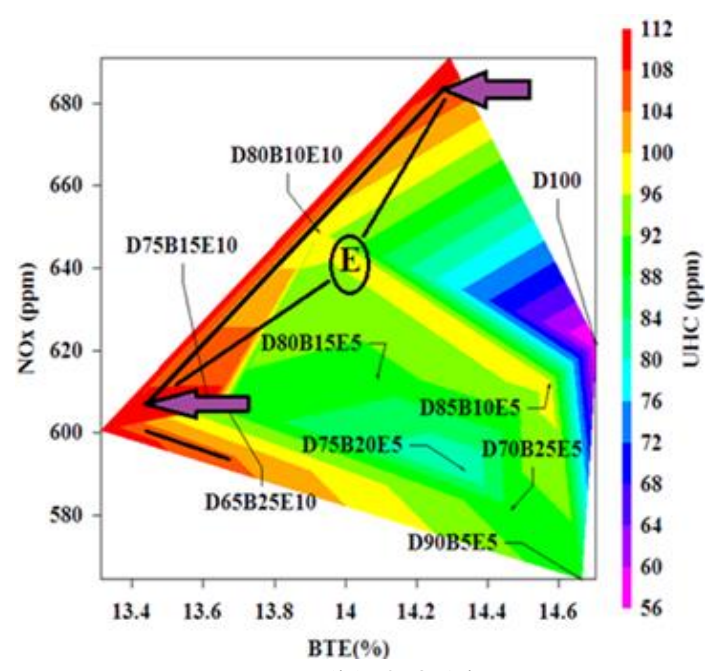

(b) $2.05 \mathrm{~kW}$

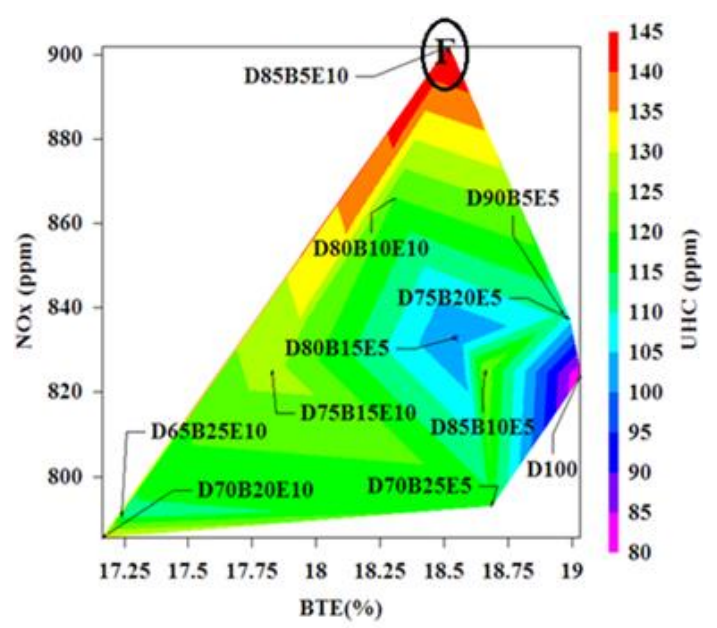

(c) $3.42 \mathrm{~kW}$

Figure 7. NOx-UHC-BTE trade-off at different brake power.

\section{CONCLUSION}

In this present study, the experiments have been performed to establish alternative use of the diesel-palm biodiesel-ethanol blend to achieve best ternary blend for engine performance and emissions. Based on the experimental results and trade-off analysis, conclusions are summarised below:

i. As compared to diesel some of the ternary blends have shown higher BTE at different brake power.

ii. As ethanol fraction increases from 5 to $10 \%$, BTE decreases due to low cetane number of the blends.

iii. The highest increase in BTE are found 2.33, 1.8, and 2.4\% for D85B5E10, D90B5E5 and D75B20E5 respectively as compared to diesel.

iv. The maximum decrease in BSEC are found 1.9, 2, and $3.24 \%$ for D85B5E10, D90B5E5 and D75B20E5 respectively as compared to diesel.

v. At medium to high load NOx emission increases due to high-temperature generation. Most of the ternary blend shows higher UHC emission which also increases with an increase in brake power. 
vi. As compared to diesel, maximum NOx reduction of 13.7, 9.17, and $4.7 \%$ and minimum UHC increase of $17,42.9$ and $24 \%$ have been observed at $0.68,2.05$, and $3.42 \mathrm{~kW}$ respectively.

vii. Performance-emission trade-off reveals the effective participation of diesel-palm biodiesel-ethanol blends among which D70B25E5 is the optimal blend which enhanced the BTE with maximum reduction in UHC and NOx emissions. It has also been observed from trade-off that most of the ternary blend with $5 \%$ ethanol addition performs at lower BSEC rate.

\section{ACKNOWLEDGEMENT}

The author's grateful thanks to the Department of Mechanical Engineering, National Institute of Technology Agartala, Tripura (West), India for supporting and giving permission for the fulfilment of this research work.

\section{REFERENCES}

[1] Mossa MAA, Hairuddin AA, Nuraini AA, et al. Effects of hot exhaust gas recirculation (EGR) on the emission and performance of a single-cylinder diesel engine. International Journal of Automotive and Mechanical Engineering 2019; 16: 6660-6674.

[2] Ali OM, Mamat R, Abdullah NR, et al. Analysis of blended fuel properties and engine performance with palm biodiesel-diesel blended fuel. Renewable Energy 2016; 86: 59-67.

[3] Dhar A, Agarwal AK. Experimental investigations of effect of Karanja biodiesel on tribological properties of lubricating oil in a compression ignition engine. Fuel 2014; 130: 112-119.

[4] Ali OM, Mamat R, Masjuki HH, et al. Analysis of blended fuel properties and cycle-to-cycle variation in a diesel engine with a diethyl ether additive. Energy Conversion and Management 2016; 108: 511-519.

[5] Mohiddin MN, Saleh AA, Reddy ANR, et al. A study on chicken fat as an alternative feedstock: Biodiesel production, fuel characterisation, and diesel engine performance analysis. International Journal of Automotive and Mechanical Engineering 2018; 15: 5535-5546.

[6] Agarwal AK, Bijwe J, Das LM. Effect of biodiesel utilization of wear of vital parts in compression ignition engine. Journal of Engineering for Gas Turbines and Power 2003; 125: 604-611.

[7] Rashed MM, Kalam MA, Masjuki $\mathrm{HH}$, et al. Performance and emission characteristics of a diesel engine fueled with palm, jatropha, and moringa oil methyl ester. Industrial Crops and Products 2016; 79: 70-76.

[8] Lee WJ, Liu YC, Mwangi FK, et al. Assessment of energy performance and air pollutant emissions in a diesel engine generator fueled with water-containing ethanol-biodiesel-diesel blend of fuels. Energy 2011; 36: 5591-5599.

[9] Qi DH, Chen H, Matthews RD, et al. Combustion and emission characteristics of ethanol-biodiesel-water micro-emulsions used in a direct injection compression ignition engine. Fuel 2010; 89: 958-964.

[10] Zhu H, Bohac S V., Nakashima K, et al. Effect of biodiesel and ethanol on load limits of high-efficiency premixed low-temperature combustion in a diesel engine. Fuel 2013; 106: 773-778. 
[11] Shahir SA, Masjuki HH, Kalam MA, et al. Performance and emission assessment of diesel-biodiesel-ethanol/bioethanol blend as a fuel in diesel engines: A review. Renewable and Sustainable Energy Reviews 2015; 48: 62-78.

[12] Abdullah Z, Suhaimi H, Abdullah A, et al. Effect of pentanol-diesel fuel blends on thermo-physical properties, combustion characteristics, engine performance and emissions of a diesel engine. International Journal of Automotive and Mechanical Engineering 2018; 15: 5435-5450.

[13] Xing-Cai L, Jian-Guang Y, Wu-Gao Z, et al. Effect of cetane number improver on heat release rate and emissions of high speed diesel engine fueled with ethanoldiesel blend fuel. In: Fuel. 2004, pp. 2013-2020.

[14] How CB, Taib NM, Mansor MRA. Performance and exhaust gas emission of biodiesel fuel with palm oil based additive in direct injection compression ignition engine. International Journal of Automotive and Mechanical Engineering 2019; 16: 6173-6187.

[15] Madiwale S, Karthikeyan A, Bhojwani V, et al. Improvement of palm oil biodiesel properties using ethanol as an additive and its effect on diesel engine performance, combustion and emissions. ARPN Journal of Engineering and Applied Sciences 2017; 12: 3987-3994.

[16] Qi DH, Chen H, Geng LM, et al. Effect of diethyl ether and ethanol additives on the combustion and emission characteristics of biodiesel-diesel blended fuel engine. Renewable Energy 2011; 36: 1252-1258.

[17] Hulwan DB, Joshi S V. Performance, emission and combustion characteristic of a multicylinder DI diesel engine running on diesel-ethanol-biodiesel blends of high ethanol content. Applied Energy 2011; 88: 5042-5055.

[18] Zhu L, Cheung CS, Zhang WG, et al. Combustion, performance and emission characteristics of a di diesel engine fueled with ethanol-biodiesel blends. Fuel 2011; 90: 1743-1750.

[19] Di Y, Cheung CS, Huang Z. Comparison of the effect of biodiesel-diesel and ethanol-diesel on the gaseous emission of a direct-injection diesel engine. Atmospheric Environment 2009; 43: 2721-2730.

[20] An H, Yang WM, Li J. Effects of ethanol addition on biodiesel combustion: A modeling study. Applied Energy 2015; 143: 176-188.

[21] Bhale PV, Deshpande N V., Thombre SB. Improving the low temperature properties of biodiesel fuel. Renewable Energy 2009; 34: 794-800.

[22] Saleh HE, Selim MYE. Improving the performance and emission characteristics of a diesel engine fueled by jojoba methyl ester-diesel-ethanol ternary blends. Fuel 2017; 207: 690-701.

[23] Tutak W, Jamrozik A, Pyrc M, et al. A comparative study of co-combustion process of diesel-ethanol and biodiesel-ethanol blends in the direct injection diesel engine. Applied Thermal Engineering 2017; 117: 155-163.

[24] Deb M, Majumder A, Banerjee R, et al. A Taguchi-fuzzy based multi-objective optimization study on the soot-NOx-BTHE characteristics of an existing CI engine under dual fuel operation with hydrogen. International Journal of Hydrogen Energy 2014; 39: 20276-20293.

[25] Deb M, Banerjee R, Majumder A, et al. Multi objective optimization of performance parameters of a single cylinder diesel engine with hydrogen as a dual fuel using pareto-based genetic algorithm. International Journal of Hydrogen Energy 2014; 39: 8063-8077.

[26] Ren Y, Huang ZH, Jiang DM, et al. Effects of the addition of ethanol and cetane 
number improver on the combustion and emission characteristics of a compression ignition engine. Proceedings of the Institution of Mechanical Engineers, Part D: Journal of Automobile Engineering 2008; 222: 1077-1087.

[27] Fang Q, Fang J, Zhuang J, et al. Effects of ethanol-diesel-biodiesel blends on combustion and emissions in premixed low temperature combustion. Applied Thermal Engineering 2013; 54: 541-548.

[28] Majumder U, Chakraborti P, Banerjee R, et al. Experimental study on the role of ethanol on performance emission trade-off and tribological characteristics of a CI engine. Renewable Energy 2016; 86: 972-984.

[29] Banerjee R, Roy S, Bose PK. Hydrogen-EGR synergy as a promising pathway to meet the PM-NO $<$ inf $>\mathrm{x}</$ inf $>$-BSFC trade-off contingencies of the diesel engine: A comprehensive review. International Journal of Hydrogen Energy 2015; 40: 12824-12847. 